\title{
Una musa de la modernidad: Laura Méndez de Cuenca (1853-1928)
}

\author{
Mílada Bazant ${ }^{1}$ \\ El Colegio Mexiquense, A.C. (México) \\ Grupo de investigación HISULA \\ mbazant@cmq.edu.mx
}

Recepción: 13/03/2013

Evaluación: 31/05/2013

Aceptación: 28/06/2013

Artículo de Reflexión

DOI: http:/ / dx.doi.org/ 10.9757/Rhela. 21.01

\section{RESUMEN}

Este trabajo aborda la trayectoria biográfica, magisterial y literaria de una de las primeras feministas de México, Laura Méndez de Cuenca. Mujer liberal y moderna, madre soltera, quien se atrevió a transgredir las normas sociales católicas de su tiempo y vivió una vida libre, pagando un precio muy alto por esa libertad. Su legado de 2000 páginas es un tratado de educación y un compendio literario de todos los géneros.

Palabras clave: Revista Historia de la Educación Latinoamericana, Mujer moderna, liberalismo, feminismo, biografía.

1 Doctora en Ciencias Sociales, El Colegio Mexiquense, A.C., Maestría en Historia, Universidad Nacional Autónoma de México, Miembro del Sistema Nacional de Investigadores Nivel I, integrante del grupo de investigación HISULA, adscrito a la Universidad Pedagógica y Tecnológica de Colombia . 
A muse of the modernity: Laura Mendez de

Cuenca (1853-1928)

ABSTRACT

This paper discusses the biographical, literary and educational career of one of the first feminist in México, Laura Méndez de Cuenca. A liberal and modern woman, single mother, she dared to transgress the social catholic rules of her time and she lived a free life but paying a high price for that freedom. Her legacy is a 2000 pages treatise on education and literary compendium of all genres.

Key words: Journal of the History of the Latin American Education, modern woman, liberalism, feminism, biography.
Uma musa da modernidade: Laura Méndez de Cuenca (1853-1928)

RESUMO

Este trabalho aborda a trajetória biográfica, docente e literária de uma das primeiras feministas do México, Laura Méndez de Cuenca. Mulher liberal e moderna, mãe solteira, atreveuse a transgredir as normas sociais católicas de seu tempo e viveu uma vida livre, pagando um preço muito alto por essa liberdade. Seu legado de 2000 páginas é um tratado de educação e um compêndio literário de todos os gêneros.

Palavras-chave: Revista História da Educação Latino-americana, Mulher moderna, liberalismo, feminismo, biografia.

\section{INTRODUCCIÓN}

Vivir y retratar una época tan espectacular y a la vez atormentada como fue la modernidad requería de la sensibilidad propia de intelectuales, poetas, filósofos que sintieran en carne propia el spleen, ese tedio agobiador, desesperanzador y a la vez pujante, vibrante, tan particular de aquella época moderna que todo lo trastocaba. Grandes pensadores como Goethe, Hegel y Marx, Stendhal, Dickens y Dostoievski transmitieron ese estado de ánimo que envolvía tanto fuerzas materiales como espirituales. Sin embargo, nadie mejor que Charles Baudelaire hizo que hombres y también mujeres tomaran conciencia de sí mismos como modernos. Si se tuviera que nombrar al primer modernista éste sería Baudelaire. No obstante, una de sus definiciones más afamadas no hace más que desconcertarnos: "Por modernidad entiendo lo efímero, lo contingente, la mitad del arte cuya otra mitad es eterna e inmutable". ${ }^{2}$

Una serie de elucubraciones acerca de este empuje externo que reacomodaba los espacios y los tiempos de forma diversa y alteraba los espíritus hacia la incertidumbre y el desconcierto fue llevando al poeta de Las flores del mal a discernir sobre esa revolución económica y cultural que envolvía

2 Marshall Berman, Todo lo sólido se desvanece en el aire. La experiencia de la modernidad, (México: Siglo XXI, 2003), 130. Ver Bolívar Echeverría, Las ilusiones de la modernidad (México: UNAM, El Equilibrista, 1997). 
a la especie humana y que eventualmente lograría transformar las fibras más profundas de su ser. Captar esa suerte de malestar y asombro que significaba el fragor de la modernidad necesitaba de la buena pluma de Baudelaire, que pudo transmitir lo que significaba el desenfreno del vapor y la electricidad en la vida material de las ciudades y paralelamente el vacío y decaimiento de la vida espiritual de sus habitantes. Sin embargo, ese vacío, esa melancolía, esa nostalgia, lo impulsaría a la recreación del arte del acomodo y de la música de las palabras, la poesía, cuyo movimiento, el modernismo, invadiría otros círculos, otras ciudades, otros países y aún otros continentes. Laura sería una ávida lectora del poeta de la modernidad, Baudelaire, y ella misma sería una impulsora de la nueva era, sobre todo tratándose de que las mujeres ocuparan también los espacios públicos, reservados para los hombres.

América, en general, también sería asiento de la modernidad. Las gentes de los campos irían a las ciudades y éstas empezarían a emerger como polos de atracción por sus fábricas, industrias, comercios, atracciones, comodidades y diversiones. Después del triunfo de la República en 1867 México se perfilaría hacia ese mundo moderno con su boom económico y su spleen espiritual. Habría un renacimiento cultural al cual pertenecería una de las mujeres más fascinantes de la historia de México: Laura Méndez de Cuenca.

Si de modernidad se trata, Laura fue una mujer moderna en toda la extensión de la palabra y digo esto porque se atrevió a transgredir las normas morales, conservadoras y católicas de su tiempo. Fue madre soltera y durante toda su vida mantuvo sola a sus dos hijos, hecho poco común en esos tiempos, y cultivó, paralelamente con sus actividades magisteriales, todos los géneros literarios cuya producción suma un caudal de más de 2000 excelsas páginas, que dejaron su impronta de mujer moderna. ${ }^{3}$ Quizás ella -como mujerencarna mejor que nadie los aires de su tiempo, la aceleración del ritmo histórico, la deslumbrante perplejidad ante lo posible, la recreación de la ciudad como territorio trepidante, pues se atrevió a vivir una vida moderna. Pero, ¿qué era una vida moderna? Las siguientes páginas mostrarán el audaz camino que eligió Laura para vivir una vida moderna, de mucho trabajo y tesón pero sobre todo, libre, pagando, por cierto, un precio muy alto por aquella libertad.

3 Mílada Bazant (coord.), Laura Méndez de Cuenca. Su herencia cultural, 3 tomos, (México: El Colegio Mexiquense A.C., Siglo XXI, 2011). Mílada Bazant, Laura Méndez de Cuenca: mujer indómita y moderna 1853-1928. Vida cotidiana y entorno, (México: El Colegio Mexiquense, A.C., 2010). 


\section{Pequeña biografía, gran historia}

La biografía como género histórico abre un versátil panorama para conocer la historia, las historias, de diversa manera. No hay mejor manera de acercarse a los varios contextos que envuelven al ser humano que la biografía, aunque se debe admitir que ésta no tiene el alcance (pues está atenida a los años que vivió la persona biografiada) para estudiar los hechos históricos de larga duración. Sin embargo, lo que sí logra agotar es la multi contextualización en un proceso dialéctico que tiene el pasado con el sujeto mismo que enriquece la agobiante univisión que generan otras historias. Generalmente, la biografía es atractiva por la vida del protagonista, no por el contexto histórico que le tocó vivir. Se sabe que el arte de este género radica en cómo el biógrafo articula la historia, arma la trama y desarrolla el relato, al tener en cuenta el arte de la poética novelesca. Más que en otro tipo de historia la prosa debe estar armoniosamente tejida, pues sabemos que la biografía oscila entre la historia y su hermana, la literatura, o para ser más precisa, la novela. Deambula entre ambos mundos y debe beber de ambos, he allí su grado de dificultad; aquí se hará referencia a la biografía histórica, que idealmente debe estar estructurada como una novela, con un clímax y desenlace, sin pisar el terreno de la invención.

En 2009 la American Historical Association organizó una mesa redonda sobre biografía que culminó en un número de la revista Historical American Review. Se sabe que tanto en Estados Unidos como en Europa la biografía es sumamente popular, hecho que no acontece en México, en donde generalmente solo se conocen las trilladas y unioculares biografías oficiales de héroes o villanos. Existen buenas biografías políticas, pero escasean, y mucho, las biografías totales, que contemplen al ser humano de carne y hueso con sus virtudes y defectos, sus penas y sus glorias. El deseo óptimo es captar el alma como lo logra, con pinceladas, un buen retratista en su lienzo.

En la mesa redonda mencionada se habló sobre los alcances de la biografía, sobre el estado en el cual se encontraba y hacia donde se dirigía. Uno de los temas más importantes que se trató fue el relacionado con el contexto histórico, analizado bajo un prisma diferente, capaz de iluminar el pasado con otra luz, otro color y otro sabor. Los contextos micro y macro, es decir, el íntimo, el familiar, el local, el estatal, el nacional y aún el internacional que necesariamente tiene que estudiar el biógrafo, lo sitúan en otra 
dimensión y comprensión del pretérito, y tan es así que algunos biógrafos han seleccionado al género biográfico no porque el o la protagonista sean atractivos sino para profundizar en determinados procesos contextuales. Como bien ha afirmado Alice Kessler-Harris - ella misma al principio renuente a este género histórico - permite entender un proceso histórico por medio de una vida, "no solo sobre eventos particulares sino en los procesos culturales, sociales y aún políticos de largo alcance, en un tiempo determinado". ${ }^{4}$

Quizás, ningún otro género histórico sea tan versátil y multiforme. La explosión de estudios sobre biografía en los últimos años conforma la numerosa escala de ópticas que ha despertado este singular género. Después de haber pasado varias décadas en la penumbra, la biografía gana cada vez más adeptos historiadores. Para unos estudiosos la parte más valiosa de una biografía yace en el conocimiento psicológico del personaje; ${ }^{5}$ otros opinan que su riqueza yace en el armonioso tejido de la vida individual con el contexto micro y macro que la determina (la mayoría de los teóricos de la biografía, entre ellos, André Maurois, Jacques Le Goff, Michel Legrand, François Dosse); algunos piensan que es la manera más amena de aprender historia pues el lector suele identificarse con las hazañas o los desmanes, las glorias y los sufrimientos de las vidas de los protagonistas y es este aspecto emocional el que nutre la lectura y la imaginación y con el cual se engancha el lector.

Para el estudio de las mujeres, la biografía en particular, abre un parteaguas en el aspecto del cómo la historia de una vida da sentido a la investigación histórica, porque analiza varios espacios y tiempos y combina algunas corrientes teórico-metodológicas: la vida cotidiana, la historia cultural, la historia de las emociones, la historia de la literatura, del arte, la condición de las mujeres y otras más, que ayudan a enriquecer la interpretación y el tejido histórico de la narración. Como bien afirma Margadant, por medio de los nuevos métodos biográficos se pueden explorar los cambios que tuvieron las mujeres en el siglo XIX y las posibilidades que algunas enfrentaron para adentrarse en la esfera pública. Su propuesta nace de la nueva biografía aquella que nació a principios del siglo XX con Lytton Strachey, quien cultivó una metodología para identificar los motivos o patrones de conducta

4 Alice Kessler-Harris, “Why biography”, American Historical Review, Vol. 114, 3 (2009): 625-630.

5 François Dosse, El arte de la biografía: entre historia y ficción, (México: Universidad Iberoamericana, 2007), 221-296. 
de determinada persona, que servirían para organizar el material de una biografía que contara una historia coherente. ${ }^{6}$ Tanto Strachey como Virginia Woolf intentaron dar a esta nueva corriente el sello moderno, al imprimir cierta dosis de psicología (el hermano de Strachey tradujo al inglés las revolucionarias obras sobre el psicoanálisis de Freud) para entender a sus personajes, no sin ciertos conflictos internos como autores, como bien lo señala Woolf en The Death of the Moth, quien intentaba dar vida a sus sujetos sin las rigideces de los hechos históricos; para ello había que convertirlos en "creativos, fértiles". La feminista concluía que la biografía era un arte "joven" y le auguraba un gran futuro; estimulaba más la imaginación que la novela y la poesía -salvo las más grandes- pues pocos novelistas y poetas eran capaces de crear aquel "alto nivel de tensión que nos da la realidad".

Uno de los puntos medulares sigue siendo aquella señalada por Strachey y Woolf: la veracidad con respecto a lo verosímil, es decir, lo factual frente a la ficción, y ello conduce necesariamente a la narración. Estos dos puntos de vista constituyen, bajo mi punto de vista, la piece de résistance de la biografía, o bajo otra óptica, los más discutidos. Sin extenderme demasiado, porque no es el objetivo de este trabajo, quisiera apoyarme en los teóricos franceses de la biografía como François Dosse, Jacques Le Goff, François Lebrun, entre otros, quienes han aceptado que para que una biografía simule una verdadera vida, debe existir una pequeña dosis de ficción, sin que ello implique "inventar demasiado". ${ }^{8}$ A modo de ejemplo: llenar ciertas lagunas históricas con base en documentos y convertir lo verídico en verosímil. Después de todo, como afirma Michel de Certeau, "el discurso histórico es ciencia y ficción porque cualquier relativismo es caduco, aunque siempre existe un contrato de verdad que debe revelarse" ${ }^{\text {"9 }}$ lo que implica "un pacto de verdad" que el autor establece con su lector a la manera en que lo propone Philippe Lejeune en su libro sobre autobiografía. ${ }^{10}$

Este trabajo se adscribe teóricamente a la escuela de la historia de la vida cotidiana fomentada en México por Pilar Gonzalbo Aizpuru, corriente teórica

\footnotetext{
6 Laura Marcus, “The Newness of the 'New Biography': Biographical Theory and Practice in the Early Twentieth Century", en Mapping Lives. The Uses of Biography, eds. Peter France y William St Clair (Nueva York: Universidad de Oxford, 2002), 193-218; Miranda Seymour, "Shaping the Truth", en Mapping Lives. The Uses of Biography, eds. Peter France y William St. Clair, (Nueva York: Universidad de Oxford, 2002), 262-263.

7 Virginia Woolf, The Death of the Moth and other Essays (Nueva York: Harcourt, Brace And Company, 1942 ), 197.

8 Dosse, El arte de la biografía, 15-24.

9 Dosse, El arte de la biografía, 431.

10 Philippe Lejeune, Le pacte autobiographique, (Paris: Seuil, 1975).
} 
basada en una serie de paradigmas de comportamiento que son comunes a muchos, a todos o a algunos seres humanos y cambian de acuerdo con el tiempo y el espacio. La utilización de ciertas fuentes poco usadas por los historiadores, como las novelas y los juicios civiles y penales y el foco micro y macro de análisis, permite adentrarse a la rutina, a la repetición o a la espontaneidad de las actividades cotidianas. ${ }^{11}$

El artículo que presento a continuación está basado en multitud de fuentes originales y secundarias, en la biografía que escribí sobre Laura Méndez de Cuenca, en su voluminosa obra literaria y pedagógica y en otra documentación que he encontrado a lo largo de mis pesquisas como biógrafa. ${ }^{12}$

\section{Tamariz: escenario de una tierra pródiga}

La vida de Laura Méndez Lefort inicia un 18 de agosto de 1853 en un alejado, pero pintoresco y tranquilo, paraje del Estado de México, al que hoy se llegaría de la ciudad de México en aproximadamente dos horas, distancia que en esa época consumía toda una jornada. En la hacienda de Tamariz a un km de Ayapango, Chalco, se establecieron los padres de Laura. Iban en busca de paz y seguridad, inexistentes en la capital debido a las continuas luchas castrenses entre los conservadores, entonces en el poder, y los liberales, que pretendían expulsarlos para iniciar así una era de libertad republicana y democracia.

Su padre, Ramón Méndez Mérida, militar y su madre, Clara Lefort Arias, hija de un afamado pastelero francés, Émile, quien llegó a México en 1824, brindaron entonces a Laura ese entorno, pensando que estaba alejado de la violencia. La pareja Méndez-Lefort se había refugiado en Tamariz, pues el dueño de la propiedad, Juan Bautista Arroyabe, le había ofrecido a don Ramón administrarla. La hacienda producía maíz y trigo y eran tareas propias de Ramón reclutar personal para la siembra, cosecha y, posteriormente, efectuar lo concerniente a la comercialización de lo producido, incluyendo el reclutamiento de mano de obra y las labores concernientes a la parte contable de la operación. ${ }^{13}$

11 Pilar Gonzalbo Aizpuru, Introducción a la historia de la vida cotidiana (México: El Colegio de México, 2006).

12 Bazant, Laura Méndez de Cuenca. Su herencia...; Laura Méndez de Cuenca: mujer indómita y moderna...

13 Este pasaje es verosímil; como no encontré fuentes en el archivo sobre la actividad de Ramón en Tamariz deduje -porque después fue administrador del rancho del Socorro - que había sido administrador de la propiedad. Archivo Histórico Municipal de Tlalmanalco (AHMT), Sesiones de Cabildo 1852-1861 y Noticias de Estadística, 1853. Alejandro Tortolero Villaseñor, De la coa a la máquina de vapor: actividad agrícola e innovación tecnológica en las haciendas mexicanas, 1880-1914 (México, El Colegio Mexiquense, A.C Siglo XXI, 1995). 
Estos primeros años de su vida dieron a Laura la oportunidad de establecer un contacto directo con la exuberante naturaleza y la riqueza geográfica. La imponente majestuosidad de los dos volcanes vecinos, el Popocatépetl y el Iztaccíhuatl, y la abundancia de los ríos provenientes de los deshielos, que no sólo aportaban fertilidad con su riego, sino también una rica fauna y flora comenzaron a despertar en su espíritu la sensibilidad y la vocación poéticas que madurarían con el tiempo, colocándola, según los literatos de la época, como la segunda Sor Juana Inés de la Cruz. Su novela, cuentos y poesía emanan pasmosas recreaciones de la belleza campirana de aquellos parajes: "[vengo del]...país de las flores/ las áureas montañas; / de las tardes azules y noches de plata". ${ }^{14}$

Pero la región no era un total paraíso. La amenazante guerra civil la había alcanzado y sufría una fuerte amenaza proveniente de la epidemia de cólera que circundaba el lugar. De esta manera, Émile, abuelo de Laura, no escatimó esfuerzos para convencer a su hija y yerno de que regresaran con su familia a la capital.

Proveniente de los Pirineos franceses, Émile Lefort había llegado atraído por la promesa de las autoridades mexicanas, que en su política de colonización concedía terrenos y algunas exenciones impositivas a aquellos inmigrantes que deseaban labrarse un futuro en estas tierras. Luchó como artillero contra los españoles, perteneció a la Guardia Nacional Mexicana, más tarde fue jefe de manzana en su lugar de residencia. Finalmente, en la aún existente Plaza de la Concepción, abrió una de las pastelerías más prestigiosas. Laura y su abuelo guardaban un particular parecido, no sólo en el aspecto físico: "pelo rubio, ojos claros y el particular mentón puntiagudo, sino además, en aquellas bien marcadas muestras de carácter, fuerza e intransigencia, tesón, disciplina, orden, espíritu de aventuras...". ${ }^{15}$

Finalmente Ramón y Clara decidieron instalarse en la Ciudad de los Palacios y, junto con sus dos hijas Rosa y Laura, se ubicaron en los "altos" (primer piso) de la pastelería de Émile.

14 Laura Méndez de Cuenca, "Tristeza”, Segundo Almanaque de Arte y Letras, México, febrero de 1896, 51. Ver Mílada Bazant (coord.), Laura Méndez de Cuenca: su herencia cultura. Tomo II. Poesía, cuentos y miscelánea, (México: El Colegio Mexiquense A.C., Siglo XXI, 2011), 88.

15 "Certificat de nationalité francaise", Archivo General de la Nación (AGN), Cartas de seguridad, vol. 197, f. 356. 


\section{La secularización, la guerra, el triunfo de la República}

Una serie de leyes, conocidas como Leyes de Reforma, fueron proclamadas en 1859 por el presidente liberal Benito Juárez. Estas se dirigieron a suprimir los privilegios que tenía la Iglesia hasta entonces y revolucionaban, hasta la médula, la estructura política, económica y social del país. En la vida cotidiana ello confundió a los mexicanos, tradicionalmente creyentes. Debido a una de las leyes, la que se refería a la confiscación y venta de los bienes del clero, la mayoría de los conventos se encontraban en proceso de demolición y/o divididos en lotes y vendidos al mejor postor. Esas transformaciones modificarían para siempre el paisaje urbano, pues se remodelaban las avenidas, nacían nuevas calles y emergían nuevas viviendas al tiempo que algunas personas provenientes de familias acomodadas comenzaban a abandonar el centro y se iban hacia el este, donde soplaba el aire más puro. Debido a la falta de baños (sólo había letrinas), agua entubada, drenaje y, por ello, carencia de higiene, la ciudad era tradicionalmente insalubre y maloliente.

Otras leyes liberales, como el establecimiento del Registro Civil, obligaban a los mexicanos a registrar sus nacimientos, matrimonios y muertes en esta oficina y no como anteriormente se realizaba, en las parroquias. También se decretó la educación laica y por primera vez en la historia de México se prohibió la enseñanza de la religión en las escuelas. Toda esta revolución política y cultural habría de vivirla Laura, una de las primeras mujeres que tendría la oportunidad de vivir la igualdad educativa para hombres y mujeres, promulgada por el mismo presidente Juárez cuando derrotó al Imperio de Maximiliano en junio de $1867 .{ }^{16}$

\section{El renacimiento cultural y educativo}

En el campo de la cultura y de la educación hubo un boom que invadió varios espacios de la vida urbana. Muchos afamados escritores se reunían en tertulias públicas y privadas y discutían no sólo sobre las obras que escribían - poesía, teatro, novela, ensayo - sino sobre los nuevos estilos literarios y sobre la cultura en general; la educación, por su parte, ocupaba un lugar prioritario. Algunos empezaron a formar parte en las modernas propuestas

16 Mílada Bazant, "La educación moderna, 1867-1911”, en Historia de la educación en la ciudad de México, coords. Pilar Gonzalbo Aizpuru y Anne Staples, (México: El Colegio de México, Centro de Estudios Históricos, Secretaría de Educación del Distrito Federal, 2012), 245-327. 
en los planes de estudio que a fines de 1867 se modificaban o bien como maestros y / o sinodales en exámenes de fin de curso en las distintas escuelas medias y superiores recientemente fundadas. En México empezaba una época de oro en la educación y en la cultura.

La ley juarista del 2 de diciembre de 1867 cambió hasta la médula el sistema educativo mexicano. Dicha ley compartía el objetivo de las Leyes de Reforma: limitar la acción de la Iglesia y excluir su dogma de la esfera pública. Como resultado de la eliminación de la enseñanza religiosa en las escuelas, el naciente enfoque pedagógico fue radicalmente distinto al utilizado en el sistema anterior. En términos prácticos, se tradujo en una metodología moderna para enseñar todas las asignaturas: el mundo ya no tenía que explicarse desde el punto de vista de la religión sino desde una base científica; la razón, por lo tanto, desplazaba al dogma y a la memoria. Comenzaría a importarse de Francia, entre otros, material didáctico moderno, como los carteles que pendían de las paredes que mostraban, por ejemplo, de acuerdo con el método objetivo, diferentes procesos de la naturaleza tales como la germinación de una semilla o bien el esqueleto humano y también se imprimirían textos escolares que tendrían este enfoque moderno, científico y racional.

En el fondo de tan novedoso enfoque estaba la doctrina positivista, traída a México por Gabino Barreda, conocido como uno de los artífices de la mencionada ley y como primer director de la Escuela Preparatoria, convertida entonces en el pilar de la educación mexicana, al ser el lugar donde se ensayaba - tal cual - el plan de estudios positivista. Su lema orden y progreso, había sido creado por Augusto Comte en Francia y caía como anillo al dedo en México, pues proponía abatir la anarquía en todas sus formas: la intelectual, la social, la económica, la doméstica y la civil. Mediante la enseñanza seriada de materias científicas, capaces de favorecer el orden mental requerido por los mexicanos. Fue así como el "cientismo" o el "cienticismo" (el abuso de la ciencia de acuerdo con los detractores) irrumpió en la educación y, con ella, en la esfera pública; los políticos vieron en los métodos científicos una contribución adaptable a la política que así impulsaría el desarrollo económico del país, lo que colaboró por ende en la regeneración social" ${ }^{17}$ La enseñanza de la religión dependería, de ahí en adelante, de la decisión de

17 Bazant, “La educación moderna, 1867-1911”, 250-280. 
las familias, éstas tenían la libertad de enviar a sus hijos, si así lo deseaban, a las escuelas católicas que siguieron manteniéndose, aunque bajo un rígida férula oficial.

\section{La educación moderna, también para las mujeres}

La ley de 1867 estableció que las mujeres tendrían las mismas oportunidades educativas que los hombres $y$, aunque pasaron muchos años antes de que el sexo femenino pudiera insertarse en la preparatoria y en las escuelas especiales (hoy facultades universitarias) - la tradición de siglos pesaba más que la ley -, las jóvenes abrazaron con fervor la carrera magisterial. La Escuela de Artes y Oficios ofreció la carrera docente, la de comerciante y artesana. Muy pronto la Escuela se saturó de alumnas y fue ahí donde Laura empezó a mostrar sus excepcionales talentos intelectuales. ${ }^{18}$

\section{Imagen 1. Laura Méndez Lefort, aproximadamente a los 18 años}

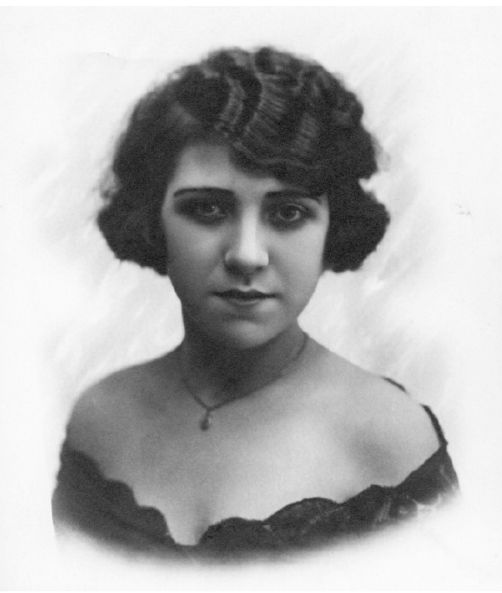

Fuente: Archivo personal de Carlos Beteta de la Garza.

Los maestros de esa escuela, y en general de todas las superiores, formaban para de lo que hoy sería excelencia académica; eran hombres enciclopedistas que enseñaban varias asignaturas, escribían libros, artículos en periódicos y, paralelamente, ejercían como funcionarios en el gobierno. Así Laura,

18 María de Lourdes Alvarado Martínez Escobar, La educación superior femenina en el México del siglo XIX. Demanda social y reto gubernamental, (México: Facultad de Filosofía y Letras, UNAM, 2001), 224. 
que había aprendido sus primeras letras en la Amiga, en la cual la religión dominaba el elenco de materias, ahora tomaba clases en la liberal Escuela de Artes y Oficios, en la cual afianzó una estrecha comunicación que le duró toda la vida: su maestro de geografía e historia universal, Enrique Olavarría y Ferrari. Pero no sólo él, había otros como Guillermo Prieto, "el poeta del pueblo" e Ignacio Manuel Altamirano, el padre intelectual de todos, con quienes Laura entabló también amistad. Y todos se reunían en las veladas literarias a las cuales asistían ocasionalmente una o dos mujeres. En uno de esos encuentros Laura conoció al poeta más querido y afamado de la República Restaurada: Manuel Acuña. Y quizás fue más querido y afamado después de su trágica muerte a fines de 1872, cuando su hijo natural, concebido con Laura, tenía escasos tres meses. El aliento de una nueva vida no fue suficiente para que Manuel no se quitara la propia.

\section{Imagen 2. Manuel Acuña}

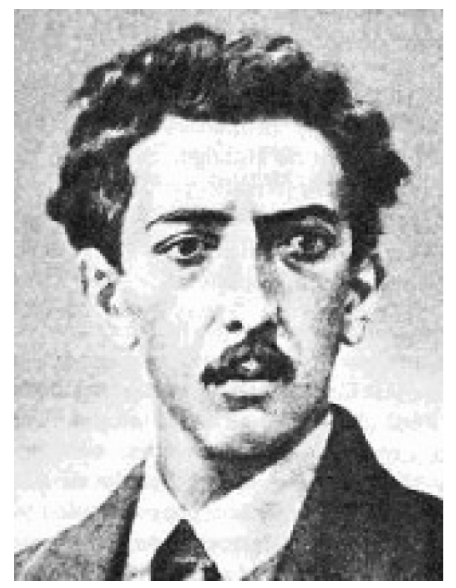

Fuente: Juan de Dios Peza, Manuel Acuña Íntimo, México, Secretaría de Educación Pública, Cuadernos Mexicanos, s.a., p. 5

El romance entre Laura y Manuel duró poco tiempo, pero lo suficiente para que ambos vivieran una atormentada relación en la cual la apasionada Laura estuvo dispuesta a darse en cuerpo y alma, y Manuel, enamorado de la Musa de los poetas finiseculares, Rosario de la Peña, no pudo corresponder más que como amigo y colega de pluma. Ambos vertieron en algunas poesías, publicadas en esos años, los sentimientos y las emociones que definían ambas personalidades envueltas en un tórrido romance comentado por todos durante y después de muchos años; de hecho, después de siglo y 
medio, sólo queda como testigo el acta del registro de nacimiento de Manuel Acuña Méndez, quien nació, como era costumbre, en casa del mejor amigo de Manuel, Agustín F. Cuenca. Este alojó a la despechada Laura cuando nadie fue capaz de tenderle una mano, ni siquiera su familia.

"A Laura" Manuel le canta a la mujer que enfrenta los convencionalismos sociales y defiende sus ideas a "cualquier precio", a la apasionada en quien percibe un "alma superior" que alcanzará tarde o temprano "la cima que desea":

Yo te lo digo Laura... quien encierra

valor para romper el yugo necio

de las preocupaciones de la tierra.

Quien sabe responder con el desprecio

a los que, amigos del anacronismo,

defienden el pasado a cualquier precio.

Quien sacudiendo todo despotismo

a ninguno somete su conciencia

y se basta al pensar consigo mismo...

Quien tiene un corazón en donde anida

el genio a cuyo voz se cubre de flores

la paramal tristeza de la vida;

$Y$ un ser al que combaten los dolores

y esa noble ambición que pertenece

al mundo de las almas superiores...

Forja un mundo en tu ardiente fantasía ya que encuentras placer y te recreas

en vivir delirando noche y día.

Alcanza la cima que deseas, mas cuando bajes de esa cima al mundo refiérenos al menos lo que veas... ${ }^{19}$

Para terminar, Acuña le vaticina "una misión sublime" que arrancará a la mujer del "oscurantismo":

19 Manuel Acuña, “A Laura”, El Eco de Ambos Mundos, México, 9 de mayo 1872. Ver Bazant (coord.), Laura Méndez de Cuenca. Su herencia cultural. Tomo II, 177-180. 
Si Laura...que tu espiritu despierte para cumplir con su misión sublime y que hallemos en ti a la mujer fuerte que del oscurantismo se redime. ${ }^{20}$

En esa poesía, Manuel alaba la personalidad individualista, liberal y de grandes alcances de Laura; no se trata de un canto de amor, sino de la loa a una hermana del Parnaso a quien se admira.

Los poemas de Laura son desgarradores; pese al evidente desaire de su amado, no reflejan el rencor de un amor no correspondido, sino el canto de una mujer enamorada. Por ejemplo, el "Adiós" que le escribió a Manuel ante una definitiva despedida:

Adiós: es necesario que deje yo tu nido las aves de tu huerto, tus rosas en botón. Adiós: es necesario que el viento del olvido arrastre entre sus alas el lúgubre gemido que lanza, al separarse mi pobre corazón... Después de tantas dichas y plácido embeleso, es fuerza que me aleje de tu bendito hogar. Tu sabes cuánto sufro y que al pensar en eso mi corazón se rompe de amor en el exceso, y en mi dolor supremo no puedo ni llorar...

Soñé que en el santuario donde te adora el alma

era tu boca un nido de amores para mi;

y en el altar augusto de nuestra santa calma cambiaba yo, sonriendo mi ensangrentada palma por pájaros y flores $y$ besos para ti. ¿Qué hermoso era el delirio de mi alma soñadora!

¿Qué bello el panorama que creaba mi ilusión!

Un mundo de delicias gozar hora tras hora, y entre crespones blancos y ráfagas de aurora, la cuna de nuestro hijo como una bendición... ${ }^{21}$

20 Bazant (coord.), Laura Méndez de Cuenca. Su herencia cultural. Tomo II, 180.

21 Laura Méndez de Cuenca, “A****”, El Siglo Diez y Nueve, año XXIII, t. 56, No. 10672, México, 29 de marzo 1874, 2, col. 5. Ver en Bazant (coord.), Laura Méndez de Cuenca: su herencia cultural. Tomo II, 34-37. 
Sólo el férreo temperamento que poseía le permitió sobreponerse a las muertes de Manuel Acuña padre, en diciembre de 1872, y luego la de Manuel Acuña hijo, en enero del año siguiente. No sólo debió sobrellevar estas penas, sino, además, hacer oídos sordos a los chismes e ignorar que la gente la señalaba cuando iba por las calles. Sólo su hermana Rosa y unos pocos amigos continuaron frecuentándola y apoyándola en su sofocante situación. La relación entre los dos poetas, Laura y Agustín, duró hasta la muerte del último y siempre se presentó difícil y con evidentes muestras de intolerancia proveniente del temperamento intransigente de ambos. No obstante, tuvieron siete hijos de los cuales sólo dos, Alicia y Horacio, alcanzaron la edad adulta.

Después de algunos años, el 18 de octubre de 1877, al tener cuatro hijos naturales, se casaron en el recién inaugurado Registro Civil y descartaron la boda religiosa, hecho que, sumado al de vivir en casas separadas por tiempos indefinidos, fue un desafío a la sociedad y a la familia constituida. Este fue un acto "moderno" decididamente marcado contra el clero. Muchos años después, Laura escribía que en el "hogar de antaño las dogmáticas malicias del catecismo católico ni aún siquiera alcanzaban a desbastar el femenil intelecto atiborrado de sandeces y de mentiras, en el cual regía pontificalmente la sagacidad de un confesor". ${ }^{22}$ Agustín, por su parte, era un furibundo anticlerical, dispuesto a batirse a duelo - literalmente - con tal de defender sus ideas. ${ }^{23}$

Ante tantos problemas, no solo de incompatibilidad de caracteres sino económicos - el periodismo que ejercía Agustín no aportaba suficientes recursos para mantener a su mujer y a su prole - decidieron trasladarse unos años a Veracruz y Orizaba, dos ciudades liberales, afines a las radicales ideas anticlericales de ambos, pero con climas extremos, la primera muy calurosa y la segunda con "fríos". Agustín logró destacar como asesor del gobernador y miembro del Ayuntamiento de Orizaba, pero ni la atmósfera social ni el dinero que percibía Agustín les proporcionaba la estabilidad que tanto necesitaban. Además, los climas no le sentaban a los hijos; Alicia tenía un temperamento exageradamente irascible; hacía continuos berrinches y Horacio

22 Laura Méndez de Cuenca, "La mujer mexicana en el nuevo hogar", El Pueblo, t. I, No. 673, México, 14 de septiembre 1916, 3. Ver en Mílada Bazant (coord.), Laura Méndez de Cuenca: su herencia cultural. Tomo III. Educación, feminismo y crónicas de viaje (México: El Colegio Mexiquense A.C., Siglo XXI, 2011), 229.

23 Por su valiente postura - en esos años los periodistas defendían sus puntos de vista a capa y espada- casi pierde la vida. Ver en Bazant, "Laura Méndez de Cuenca, mujer indómita y moderna", 146-149. 
padecía de intermitentes catarros. Sin embargo, lo que convenció a la pareja a regresarse a la ciudad de México, a fines de 1883, fue el agudo malestar generalizado de Agustín quien, pese a una operación, murió de "hepatitis supurada" el 30 de junio de 1884. Nuevamente las crisis emocionales hicieron impacto en el ánimo de Laura y sólo la realidad de sus dos hijos enfermos la eximió de la depresión, lo que la impulsó a continuar por ellos.

\section{Sus agallas "varoniles"}

Desde que Laura estuvo en la Escuela de Artes y Oficios había contemplado la idea de convertirse en maestra y de hecho había cursado ahí algunas materias como gramática, geografía e historia, así que empezó a prepararse para el examen ante el Ayuntamiento de la ciudad de México. No tenía ni tiempo ni dinero para estudiar en forma escolarizada -trabajaba ya como maestra en una escuela municipal, sin título, como el $90 \%$ de los maestros. En esa época todavía no existía la Escuela Normal - ésta se fundó en 1890 - pero se podía obtener el grado preparándose en forma individual, como Laura, o bien en alguna academia o bien en la Secundaria para Niñas, en el Colegio de la Paz o Vizcaínas o en algún colegio privado.

\section{Imagen 3. Laura Méndez de Cuenca, aproximadamente a los 30 años}

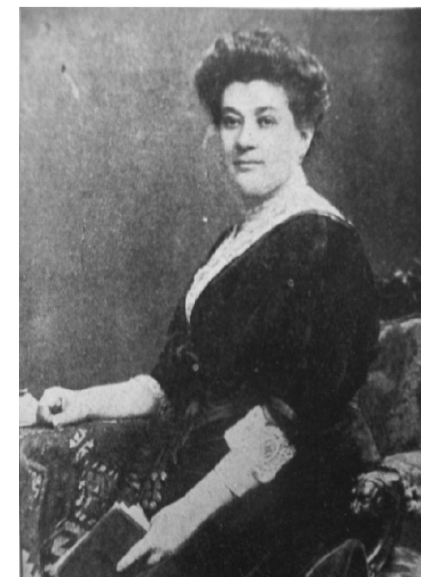

Fuente: Instituto de Investigaciones Bibliográficas - Fondo Enrique Olavarría y Ferrari, Universidad Nacional Autónoma de México, Hemeroteca Nacional, México. 
A partir de entonces le robó horas a las noches y minutos a los días; su vida se convirtió en una máquina de esfuerzo y trabajo y de trepidante curiosidad intelectual. Se volcó en los libros y se olvidó de sí misma; su vida social se redujo a lo mínimo; en realidad su trabajo de maestra de ocho a doce de la mañana y de dos a cinco de la tarde, sumado al cuidado de dos hijos continuamente enfermos y al de sus labores cotidianas, la dejaban extenuada. Eventualmente, con la exagerada carga doméstica y docente se enfermaría de "histeria", un malestar que le daba a las mujeres (hoy en día algunos médicos la comparan con la fibromialgia, también enfermedad de mujeres) por ser "ociosas", cualidad propia de las provenientes de clases altas o por exceso de trabajo como en el caso de Laura. ${ }^{24}$

Finalmente, el 17 de noviembre de 1885 Laura obtuvo su título de maestra. Con aquel documento en mano pensó que entraría al magisterio por la puerta grande y que el Ayuntamiento le ofrecería un mejor empleo. Sin embargo, con su mala fama a cuestas y su difícil y complejo carácter pronto se dio cuenta que lo primero pesaba demasiado socialmente para poder llevar una vida tranquila. Empezó a elucubrar en irse a vivir fuera de México, una idea descabellada para una mujer sola con dos hijos; sin embargo, no lo era para una mujer como ella, fuerte, segura y deseosa de emprender nuevos retos.

Después de darle mil vueltas al asunto, logró concretizar sus planes en julio de 1891 cuando llegó a una ciudad cautivadora por su belleza y cosmopolitanismo: San Francisco, California. La ciudad y el estado de California habían pertenecido a México desde la época de la colonia española. Sin embargo, en 1848 perdió ese territorio, más otros estados mexicanos, Texas y Nuevo México, en una desventajosa guerra contra los americanos. Justo en ese año, un agricultor del valle de Sacramento halló oro en el río Americano. La fiebre del metal desquició a la sociedad norteamericana, la población creció de 92 almas a 380000, todas buscando hacerse millonarias de la noche a la mañana. La locura del oro desquició la economía, escaseaban los víveres, las cosas se pagaban con pepitas de oro, todo el mundo se hallaba engolosinado con la gold rush y nadie producía. En 1850 California se convirtió en un Estado americano y la estabilidad empezó a aflorar poco a poco; los aventureros abandonaron la ciudad y San Francisco recobró la paz, empezó a prosperar la economía y a distinguirse por ser una urbe

24 Bazant, “Laura Méndez de Cuenca, mujer indómita y moderna”, 178-179. 
especialmente culta y cosmopolita. Cuando Laura llegó estaba en pleno apogeo, en todos los sentidos de la palabra.

Del arrojo que tuvo Laura para expatriarse, se dijo que se debía a uno de "sus arranques varoniles que mucho la distinguen, [...es una] mujer cuya virilidad y energías femeninas podrían envidiarle muchos hombres" y que además no hablaba una palabra en inglés. ${ }^{25}$ Posteriormente, varias veces en su vida, la calificaron con cualidades propias de hombres; a los setenta años todavía la llamaban, i “virago desaforada"! ${ }^{26}$ Sea como fuera, lo cierto es que la maestra mexicana mostró, con tal decisión, un férreo temperamento capaz de mover montañas, hazaña que en realidad sólo ella - como mujer - fue capaz de hacer. Como Laura ganaba en todo lo que emprendía, sus años en San Francisco la convirtieron en una mujer segura, libre, moderna y profesionalmente destacada, no sin una buena dosis de preocupación por sus hijos enfermos. Pese a ello, Alicia y Horacio, quienes llegaron a San Francisco de 11 y 13 años, cuando regresaron a México, después de nueve años, ya se habían convertido - más por el empuje y empecinamiento de su madre que por ellos mismos - en impresor, el primero y en normalista, la segunda.

Como toda mujer culta, Laura eventualmente aprendió varios idiomas: francés, inglés y alemán, sánscrito y latín. Conocía mucho de pedagogía y de literatura. En San Francisco escribió páginas deslumbrantes; una novela costumbrista, El Espejo de Amarilis; varios cuentos, poesía y artículos diversos para periódicos mexicanos. ${ }^{27}$ Todo ello le valió para ser considerada como la mejor escritora mexicana del siglo XIX ${ }^{28}$ Quizás Laura fue la única mexicana que, en esa época, se ganó la vida escribiendo - y también impartiendo clases de español a gringas copetudas que le pagaban la hora un dólar y medio, lo mismo que el gobierno mexicano le retribuía por un mes de sueldo -. Cierto que el costo de vida en San Francisco era mayor, pero en aquel lugar Laura vivió por primera vez con toda suerte de comodidades, hasta con holgura, y sobre todo con la libertad que tanto ansiaba; nadie la señalaba y en aquel sitio las mujeres ganaban al parejo de los hombres.

25 P. P., en el suplemento Jueves de El Mundo. Ilustración Popular, México, 12 de junio, 1902. Ver Bazant, Laura Méndez de Cuenca, mujer indómita y moderna, 193.

26 Tina Escaja (comp.) Delmira Agustini y el Modernismo. Nuevas propuestas de género, Rosario: Beatriz Viterbo Editora, 2000, 145.

27 Además de la obra que recopilo en tres volúmenes, Laura escribió 1. Impresiones de viajes (artículos); 2. Un volumen de cuentos cortos; 3 . Vacaciones. Novela de costumbres mexicanas; 4. Los preciados. Novela de costumbres mexicanas; 5 . La dicha... hay que atraparla; 6. Eureka, comedia en tres actos; 7. La ley del embudo, Zarzuela en tres actos; 8. Carmen, drama en tres actos; 9. Novela de costumbres sin título; 10. Tres libros de lectura. Ver en el Archivo Histórico de Ramón Beteta, en el Colegio de México (AHRB), caja 49, exp. 321.

28 Ver los prólogos de los tomos II y III de la Obra de Laura Méndez de Cuenca. 
En general, el feminismo, entendido para una mujer culta como Laura, no era otra cosa que la lucha de las mujeres por tener el mismo derecho de oportunidades y salarios que los hombres. Y la maestra, al igual que muchas mujeres de San Francisco, ejerció esos derechos y su vocación de mujer moderna. Asistió a las veladas literarias y se vinculó con gente de letras, de educación, de la diplomacia, de la crème de la crème. En una de esas reuniones conoció al cónsul de Argentina, José Schleiden; al cabo de un tiempo ambos fundaron la Revista Hispanoamericana, destinada a circular por todo el continente (imagen 4). Totalmente bilingüe, ofrecía intercambio comercial con los países latinos; en ella se anunciaban los artículos modernos más vistosos y de todas las ramas, como arados, trituradoras, desgranadoras; plantas y árboles exóticos, como por ejemplo la araucaria de Chile; inodoros, coches; en fín, todo lo relacionado con el último grito del comercio y de la industria. De esos anuncios y de las suscripciones vivía la Revista; el tiraje ascendía a 4000 ejemplares. Laura era la editora y Schleiden el administrador. Las oficinas se ubicaban en el primer rascacielos de la ciudad, el Mills Building donde estaban los industriales más connotados como Hearst, emporio de periódicos y Oliver, de máquinas de escribir. Laura había logrado colocar a Horacio como impresor de la revista. Así dio comienzo la vocación de Laura de convertirse en editora, concebida a lo grande, como cualquier empresa yanqui. Las ganancias netas ascendían a 1000 dólares al mes. ${ }^{29}$

\section{Imagen 4. Portada de la Revista, enero de 1896}

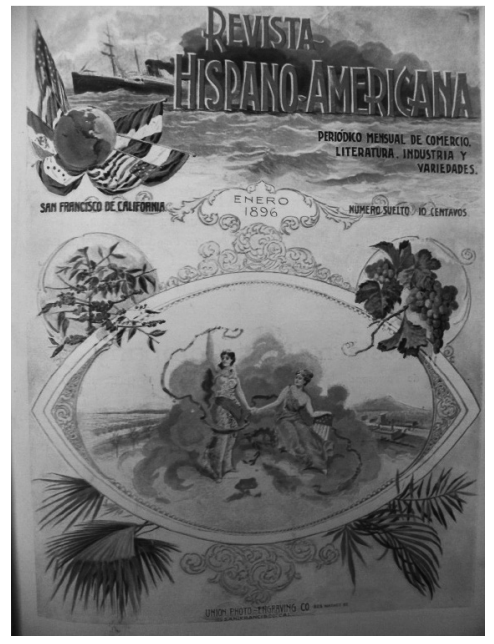

Fuente: Revista Hispanoamericana, Instituto de Investigaciones Bibliográficas - Universidad Nacional Autónoma de México, Hemeroteca Nacional, México.

29 Bazant, Laura Méndez de Cuenca, mujer indómita y moderna", 208-212. 
Quizás debido a su falta de experiencia a Laura no se le ocurrió que debió haber firmado un contrato de la sociedad, pues un buen día, de la noche a la mañana, su socio le arrebató la Revista. Sin ningún papel que la acreditara como socia, el pleito estaba perdido. $Y$ así murieron sus sueños de ser editora... por el momento. Se levantó de ese golpe y el destino le trajo otro reto: el gobernador liberal del Estado de México, José Vicente Villada, amigo de letras durante su atribulada juventud, la invitó a que fuera subdirectora de la Escuela Normal de Toluca (el director era el secretario general de gobierno, pero era más de palabra que de facto), una institución flamante, moderna, concebida de acuerdo con la pedagogía en boga, con 300 alumnas internas y externas. Laura aceptó este nuevo reto y dejó a sus hijos en San Francisco, pensando en que esa independencia los haría madurar e independizarse económicamente de su madre.

Pese a todos sus méritos, Laura era demasiado directa e intransigente. Y la vida le había enseñado que el orden, la disciplina y el conocimiento era la tríada que se necesitaba para salir del atraso y vaya que México estaba atrasado; en 1895 el $85 \%$ de la población no sabía leer ni escribir. ${ }^{30}$ El brusco cambio de la liberal San Francisco a la tradicional Toluca la dejó, en primera instancia, sin aliento. En Toluca las mujeres no salían solas a la calle, salvo cuando iban a misa; su pasatiempo consistía en espiar a la gente que pasaba, tras los visillos de las ventanas. Con su visión y experiencia de toda una mujer moderna, quiso cambiar las cosas demasiado pronto y se dio de topes con todo el personal, maestros y alumnas. Deseaba modificar de tajo inercias anquilosadas, comportamientos viciados, conductas llevadas a medio camino, aprendizajes mediocres; en fín, su experiencia no duró más que unos meses; su hartazgo coincidió con una crisis de nervios de Alicia en la lejana San Francisco, adonde la atribulada madre había dejado a su hija en una institución especial para que la cuidara. ${ }^{31}$

\section{Su calibre de mujer moderna}

Cuando Laura llegó, después de casi una década, a la ciudad de México, vaya que observó cambios. La electrificación, el drenaje, las nuevas calles empedradas o pavimentadas, el teléfono, las bicicletas, los patines, los automóviles, las emergentes colonias y fraccionamientos, los edificios

30 Mílada Bazant, Historia de la educación en el Porfiriato (México: El Colegio de México, 2006), 95.

31 Bazant, "La educación moderna, 1867-1911", 290-300. 
en construcción, como el de Correos y el de Bellas Artes, y muchas cosas más, propias de la modernización y el progreso. Después de tanto tiempo, parecía que sus compatriotas le habían perdonado sus pecados de juventud y algunos intelectuales empezaron a llamarla la segunda Sor Juana porque, en efecto, su obra poética era tan grandiosa como la de la Décima Musa. Pero no sólo eso, había conocido varias escuelas en San Francisco y sabía mucho de pedagogía, de tal suerte que quería hacérselo saber al Subsecretario de Instrucción Pública, Justo Sierra.

La educación en México recién se había centralizado, es decir, por su tradicional pobreza, los ayuntamientos ya no se hacían cargo de las escuelas y tanto el gobierno federal como los estatales administraban la educación. En 1889-1890 y 1891 se habían llevado a cabo dos Congresos de Instrucción, a raíz de los cuales se había implantado la enseñanza moderna, basada en la razón, que sustituía a la antigua memorista. Se habían organizado los ciclos escolares, se había reglamentado la manera de examinar y, muy importante, se había adecuado la educación a las condiciones mexicanas al crear tres tipos de escuelas, de primera, segunda y tercera clase, de acuerdo con el tipo de población a la cual iba destinada y de acuerdo con la cantidad del impuesto de instrucción pública que pagaban los habitantes.

\section{Imagen 5. Escuela de niñas de primera clase, con mapas, carteles e ilustraciones modernas}

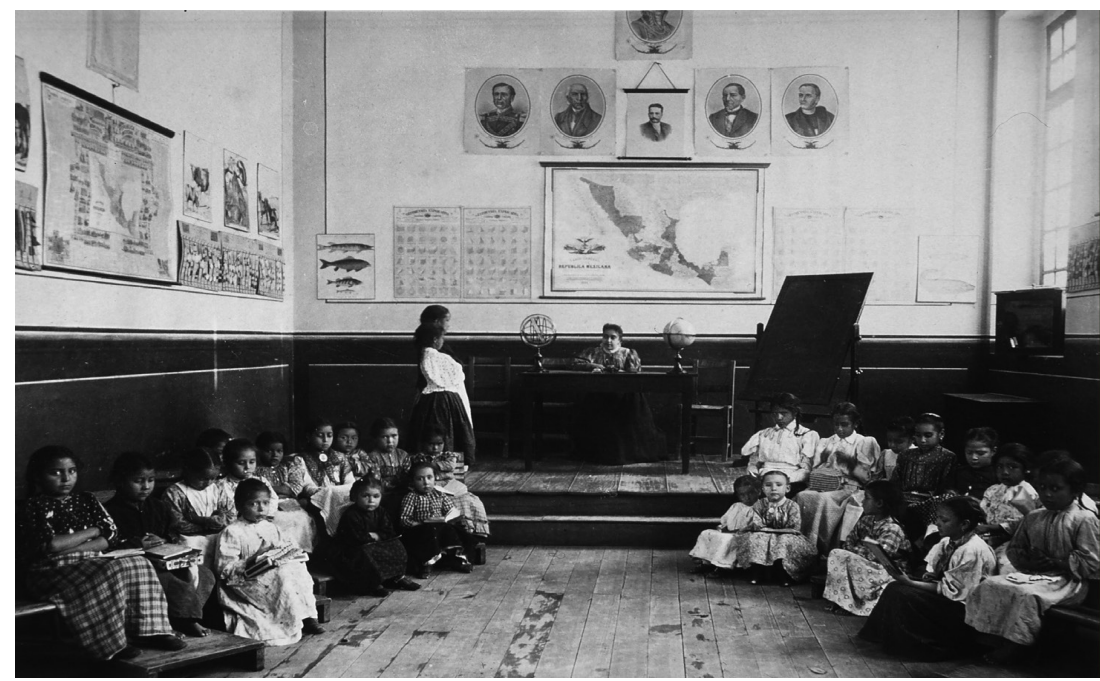

Fuente: Escuela de primera clase en Toluca, Archivo Histórico del Estado de México, Fototeca. 
La revolución educativa se sumaba a la creación de las Escuelas Normales $y$ al vertiginoso incremento del sexo femenino dentro del magisterio. Sin embargo, comparado con San Francisco, los sueldos de hombres y mujeres diferían, así como también las condiciones de trabajo. Y Laura luchaba no solo por la igualdad de los sexos en sueldos y oportunidades sino para que la mujer estudiara y trabajara, es decir, tuviera derecho a la "verdadera vida". "[...] Parte de la especie humana quiere tener derecho a la verdadera vida, a la intelectual que es la luz y no a la del topo a que se le ha condenado [... ]" Pide (la mujer) "en nombre de la justicia que se la dote convenientemente para la lucha por la vida; que se la respete de día y de noche y en todo lugar; que se la remunere por su trabajo al igual que al hombre [...]".32

La primera década del siglo veinte vaticinaba a Laura glorias y nuevos retos, premios y distinciones. El gobierno mexicano la envió primero a San Luis, Missouri y después a Berlín - su reto personal consistió en aprender perfectamente bien el alemán -, con el objetivo de estudiar ambos sistemas educativos y observar qué de aquello podía implementarse en los planteles mexicanos. Laura no fue la única pero ciertamente se distinguió por enviar informes sesudos, de índole comparativa. Criticó mil y un asuntos: el atrasado y memorístico aprendizaje en las aulas mexicanas, los castigos corporales, el magisterio femenino volcado más a la presunción que a la vocación, el nepotismo de las autoridades, los exámenes orales, cuando debía haberlos escritos. Pero no sólo criticaba, también proponía cambios concretos que llegaron en forma escrita a las autoridades; algunos, como el de los exámenes, llegaron a aterrizar en forma concreta muchos años después.

No le bastó visitar escuelas, pues su obsesión la llevaba a buscar todos los caminos posibles para enriquecerse intelectualmente, de tal suerte que, así como recorría planteles y leía obras pedagógicas, también se relacionaba con pedagogos y gente de renombre. En San Luis la invitaron a que formara parte de la prestigiosa Society of Pedagogy; en la misma ciudad representó a México en un Congreso de Educación y posteriormente en Europa asistió a varios foros sobre Educación, Mutualismo e Higiene.

En 1904, cuando regresó a México de San Luis, fue invitada a presidir una sociedad feminista que tenía por objeto "el perfeccionamiento físico,

32 Laura Méndez de Cuenca, "El decantado feminismo", El Imparcial, T. XXIII, No. 4065, México, 17 de noviembre 1907, 10-11. Ver Bazant (coord.), "Laura Méndez”. Tomo III, 217. 
intelectual y moral de la mujer" y sostenía como vehículo ideológico, La Mujer Mexicana, periódico en el que Laura y otras mujeres publicaban artículos variados que pudiesen ser de interés para el sexo femenino. Entre los que Laura publicó destaca una tríada, Las necesidades de México, en las cuales daba su punto de vista, novedoso para la época, acerca de los tres componentes que se necesitaban para mejorar a la población: educación, alimentación e higiene, sin el mejoramiento de esos tres factores -vaticinabaMéxico no saldría de su atraso. Generalmente, los educadores de entonces pensaban que la educación por sí misma sería capaz de cambiar el nivel socio-económico de la población.

Pese a sus múltiples méritos, entre ellos haber publicado una novela, hecho que pocos escritores lograban, parecía que la vida le cobraba a Laura todos sus éxitos, con tragedias cada vez mayores. Estando en San Luis, murió, el 17 de julio de 1902, su hijo Horacio en México, víctima del tifo, enfermedad que provenía del piojo o pulga de la rata. De alguna manera, Laura nunca pudo sobrellevar esa pena; quizás, en parte, porque sentía haber sido una madre demasiado severa y exigente con un hijo especialmente débil y enfermizo. Su última voluntad de querer descansar para siempre con Horacio habla más allá de un amor profundo de madre hacia su hijo; su última voluntad estableció que cuando ella muriera los "restos áridos" de Horacio fueran sacados de su tumba para ser enterrados en el mismo sepulcro que su madre.

Así, a partir de 1902 sólo le sobrevivía en su vida cotidiana la caprichuda de Alicia, que para entonces tenía 23 años y se había hecho cada vez más difícil. Mi hipótesis es que sufría de esquizofrenia, paranoia, bipolaridad o alguna enfermedad mental parecida. Desgraciadamente, poco se conocía sobre los padecimientos mentales, de tal suerte que su madre sólo podía darle baños de asiento con agua fría y proporcionarle cloroformo y cloral en situaciones extremas. En la rutina cotidiana el té de valeriana o tila eran los remedios usuales. Cuando se inauguró el Manicomio de La Castañeda, en 1910, Alicia pudo internarse por tiempos indefinidos. Dios quiso que sobreviviera a su madre, pero la historia oral de la familia cuenta que golpeaba las paredes, se azotaba contra ellas y rompía vidrios con sus puños; incluso corría la historia de que se había suicidado aventándose de la azotea. Ello no fue cierto, murió en 1937 víctima de pulmonía. 
Para la gran mayoría de la crème de la crème de la intelectualidad mexicana, París era la ciudad de los sueños, emblema de la capital cultural del mundo occidental, ya que en ella se concentraba todo el arte y la ciencia del siglo XIX y lo que estaba de vanguardia. Todo mexicano culto aspiraba visitar la Ciudad Luz y muchos hablaban francés a la perfección.

Con relación a la educación, París era la cuna inspiradora de ideales y de prácticas. Ahí se había llevado a cabo el Congreso de Educación de 1880, mismo que inspiró uno similar en la ciudad de México a fines de 1889 y que marcó los lineamientos de la nueva escuela moderna mexicana. A París fueron varios maestros y maestras, Laura incluida - aunque solo asistió a dos congresos - a aprender sobre la pedagogía en boga y a remitir informes al gobierno mexicano sobre lo observado y lo aprendido. Contra la opinión de sus contemporáneos, a Laura le decepcionó la suciedad y el bajo mundo de la sensualidad parisinos (ya madura, la maestra se hizo una moralista intransigente) y más que ello, opinó que los franceses, siempre ufanos de ser bien elevés, se comportaban (se refiere en sus actitudes dentro de los congresos) con presunción e incluso ironía. Para su suerte, el gobierno mexicano le impuso un reto mayor: trasladarse a Berlín, también sede de novedosas pedagogías, disciplinas y ejercicios manuales y gimnásticos. Llegó cuando Alemania estaba en su esplendor, como sede de la ciencia y la educación, en tiempos en que reinaba el ilustrado Otto von Bismarck.

Para visitar las escuelas alemanas, como lo exigía Laura Méndez de Cuenca, es decir, a fondo, se requería saber alemán y así se propuso, primero que nada, aprender "en cuerpo y alma a dominar a mi monstruo alemán". Luego, se dio a sus anchas estudiando las escuelas elementales, medias y superiores, de hombres y de mujeres y mixtas; nadie se lo exigía (o sea el gobierno la obligaba a informar sólo sobre las elementales), pero a ella le interesaba todo, tenía obsesión por el conocimiento; como ella misma escribió en un ensayocuento autobiográfico, "La confesión de Alma", su afán de perfeccionamiento nunca llegaba a satisfacerse. Sus bitácoras conforman, para el estudioso de la historia de la educación, una excelente fuente para estudiar no sólo el sistema educativo alemán sino el mexicano e incluso el estadounidense, ya que en ellas emplea la índole comparativa. ${ }^{33}$ Entre muchas cosas le sorprendió

33 Laura Méndez de Cuenca, “Informe del Kindergarten de Saint Louis Missouri”, en Archivo Histórico de la Secretaría de Educación Pública (AHSEP), Personajes sobresalientes, Laura Méndez de Cuenca, leg. 1, 27 de enero de 1903, fs. 29. Laura Méndez de Cuenca, "Informe sobre el sistema de educación popular en Alemania. Primera parte" (27 de enero de 1908), AGN, Secretaría de Estado y del Despacho de Instrucción Pública y Bellas Artes. "Informe sobre el sistema de educación popular en Alemania. 
que, después del aprendizaje de la lengua nacional, ¡los niños alemanes aprendieran religión!, tema que en México estaba vetado desde 1861!

Si la profesora Laura Méndez fue alguna vez feliz ello aconteció en Berlín, donde el orden, la paz, la limpieza, la buena alimentación y la higiene conformaban, como los dedos de una mano, los cinco elementos que toda nación civilizada y moderna debía poseer para alcanzar el bienestar de la justa medianía. El país de sus sueños fue Alemania, quizás porque el temperamento teutón y la disciplina prusiana iban más de acuerdo con sus propias características innatas y aprendidas.

Para completar el sueldo-beca que le enviaba el gobierno mexicano, la incansable Laura impartía clases de español y en las vacaciones cumplía su sueño dorado de viajar y explorar territorios nuevos. Cosmopolita hasta las entrañas, Laura deambulaba sin miedo por ciudades, parques, hospitales, museos, fortalezas, castillos y todo cuanto atrapaba su curiosa mirada, auténticos festines para su inteligencia. Ésta era una de las características de los hombres y mujeres modernos: una insaciable curiosidad por conocer ese mundo que todo lo trastocaba. Testimonio de ello son sus interesantes crónicas escritas entre 1907 y 1910 para El Imparcial y otros periódicos. ${ }^{34}$ Cientos de cuartillas reflejan sus preocupaciones sociales en el terreno de la educación, la salud y la higiene, pero también la inquietaban otros asuntos como la desigualdad educativa y laboral entre hombres y mujeres. Pese a su radicalismo, Laura consentía en que la felicidad del bello sexo se encontraba tanto en el espacio doméstico - como esposa y madre - como en el formativo, ya fuera en la escuela o en el trabajo. Su experiencia en los Estados Unidos la tornó conciliadora, pues en aquel país las mujeres eran demasiado libres y la maestra observaba que no eran felices ninguneando a los hombres y dejando a los hijos a la deriva.

\section{8. ¿Venganza de los gobiernos revolucionarios?}

Cuando se celebraron las apoteóticas Fiestas del Centenario, en septiembre de 1910, nadie se imaginaba la catástrofe que se avecinaba. Al poco tiempo,

\footnotetext{
Segunda parte" (13 de julio de 1908), AGN, Secretaría de Estado y del Despacho de Instrucción Pública y Bellas Artes. Ver Bazant (coord.), Laura Méndez de Cuenca: su herencia cultural. Tomo III, 55-159.

34 Bazant (coord.), Laura Méndez de Cuenca: su herencia cultural. Tomo III, 399-771.
} 
el 20 de noviembre, se desató el movimiento social conocido como la Revolución Mexicana. Duró diez años, costó un millón de vidas y devastó a México en todos los sentidos; sin embargo, también sacudió conciencias. Los ideales de repartición de tierras y de justicia social quedaron bajo los estragos del complejo entramado revolucionario, ya que en su seno y bajo las míticas figuras de Madero, Zapata, Villa, Carranza y Obregón se tejían y desaparecían alianzas, perfidias y traiciones.

Los porfiristas que pudieron abandonaron el país, pero otros, sin recursos como Laura, tuvieron que padecer una suerte de venganza de los supuestos gobiernos revolucionarios por haber sido colaboradores del gobierno de Porfirio Díaz. Recién llegada de Europa, en el verano de 1910, Laura fue ascendida al máximo puesto dentro del escalafón magisterial, el de inspectora; sin embargo, tal cargo debía llevarse a cabo en una zona indígena muy pobre, Milpa Alta, alejada de la ciudad y sin comunicación; es decir, había que ir a pie o a caballo. Para una mujer diabética, de 57 años, ello parecía más castigo que premio. Ahí empezó su largo deambular docente, agravado por la escasez de recursos derivada de la anarquía revolucionaria. En ocasiones, los profesores esperaban día y noche, en fila, para obtener su retribución. Laura fue cambiada de puesto en varias ocasiones y la degradaron al darle el más bajo del escalafón, el de ayudante. Ciertamente, Laura Méndez tenía carácter difícil, pero a esas alturas y con tanto prestigio a cuestas no se merecía ese maltrato, por lo que presumo, ello resultaba de haber trabajado para el gobierno de Porfirio Díaz. Por otra parte, padeció, como todos los mexicanos, los estragos del pillaje de los revolucionarios y durante algún tiempo se vio forzada a abrir un tendajón. Con todo, en aquellos diez años la maestra escribió algunos impactantes artículos sobre la mujer "iluminada con la antorcha de la Revolución [...] reclama ante todos los privilegios a que tiene derecho el inestimable de la libertad" ${ }^{\prime 35} \mathrm{y}$, paralelamente, la siguió acompañando su fiel amiga, la poesía.

Terminada la revolución, el brillante escritor José Vasconcelos ocupó en 1921, bajo la presidencia de Álvaro Obregón, la cartera de educación. Laura tenía la suerte de conocerlo ya que ambos habían sido miembros, en

35 Laura Méndez de Cuenca, "La mujer mexicana moderna en el nuevo hogar", El Pueblo, t. I, núm. 673, México, 14 de septiembre de 1916, 16. Ver Bazant (coord.), Laura Méndez de Cuenca: su herencia cultural. Tomo III, 230. 
1914, del prestigioso Consejo Superior de Educación, órgano encargado de estudiar los temas y problemas educativos y proponer posibles soluciones. Ya como Ministro, Vasconcelos realizó una de las reformas educativas más interesantes en la historia de México: combatir el analfabetismo por medio de campañas que involucraban también, el mejoramiento de la higiene y la salud de los habitantes. Aunque Laura cooperó en aquel proyecto, ya para entonces estaba abatida, desilusionada del pusilánime ambiente magisterial y enferma, de tal suerte que empezó a tramitar su merecida jubilación, en teoría, reglamentada en la reciente Ley de Pensiones. Paralelamente, asistía a la Universidad a tomar, como alumna regular, varios cursos de lengua y literatura; de entonces se conservan sus ensayos y sus calificaciones.

Finalmente, después de 42 años de servicio, el gobierno federal le concedió, en septiembre de 1925, su jubilación con el raquítico sueldo diario de 7,50 pesos, cantidad equiparable a la de un mozo o escribiente. Se retiró a su casita, en el barrio de San Pedro de los Pinos, la que construyó a su regreso de San Francisco con una pequeña herencia que había recibido de su esposo Agustín, sumada a sus propios ahorros. Ahí tuvo una selecta biblioteca rica en tratados escolares y de moderna metodología, de literatura y de historia. No tuvo reparo en comprar un inodoro y una cocina modernos, tal cual los había observado en San Francisco y que ya se vendían en México. El cómo debía vivir una mexicana "moderna" fue tema de un texto escolar, El hogar mexicano. Lecciones de economía doméstica, útil manual que se editó tres veces y en el cual la Méndez enseñaba, auxiliándose de imágenes, los hábitos y costumbres modernas que debía aprender una jovencita mexicana para vivir sana y feliz, aquello que la propia autora logró sólo en su imaginación. En aquella casa moderna mexicana, la mujer podría poseer un estudio o biblioteca, idea precursora del "cuarto propio", de Virginia Woolf, que debían tener las escritoras profesionales. ${ }^{36}$

36 Leticia Romero Chumacero, “Un impulso de solidaridad: el feminismo de Laura Méndez de Cuenca”, en Laura Méndez de Cuenca: su herencia cultural. Tomo III, 189-204. 


\section{Imagen 6. Portada de la tercera edición de El hogar mexicano, segunda parte}

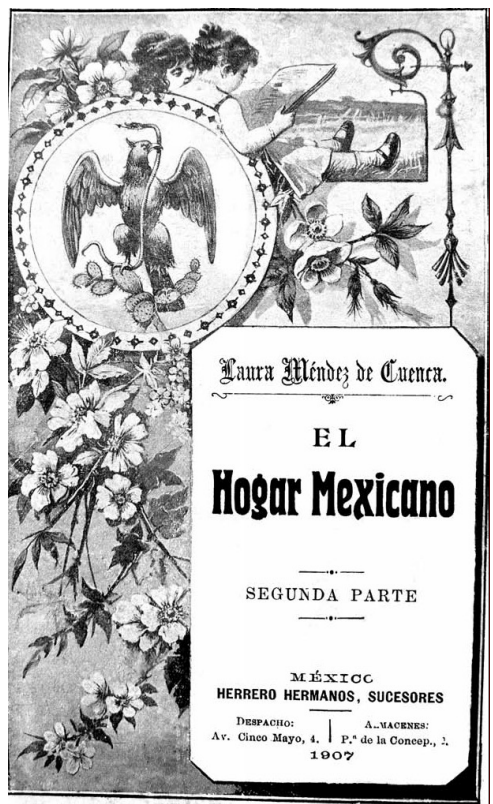

Fuente: Portada de El Hogar Mexicano, de Laura Méndez de Cuenca. Instituto de Investigaciones Bibliográficas, Universidad Nacional Autónoma de México, Hemeroteca Nacional, México.

Imagen 7. Baño moderno con tres piezas, lavabo, tina y W.C., tal como deseaba Laura que tuvieran todos los hogares mexicanos

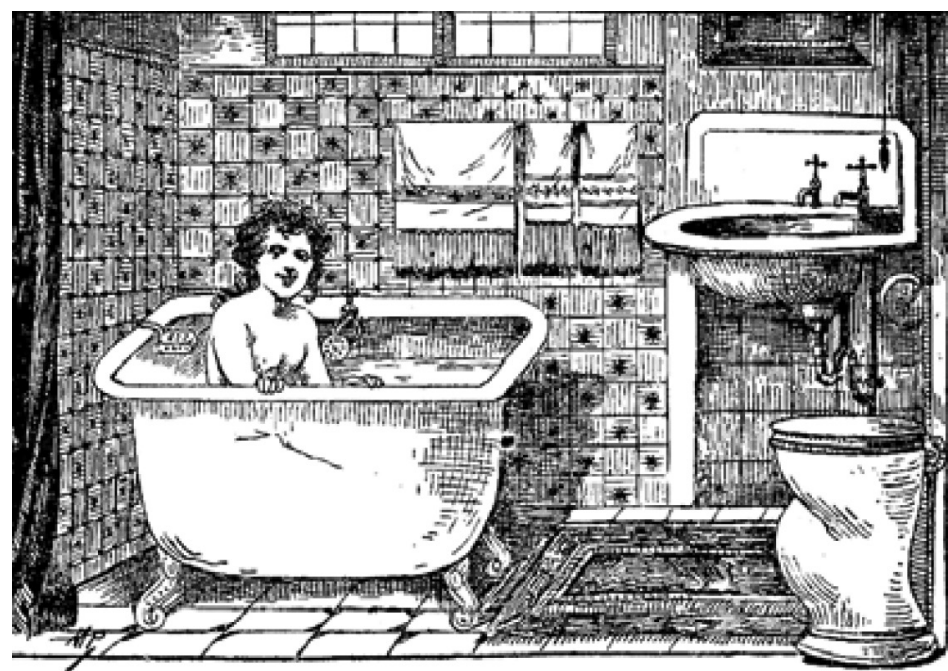

Fuente: Baño de agua tibia, en El hogar mexicano, primera parte, Instituto de Investigaciones Bibliográficas, Universidad Nacional Autónoma de México, Hemeroteca Nacional, México. 
Cuenta la historia oral que los meses que antecedieron al viaje sin regreso, Laura pasó muchos meses en cama, debilitaba en grado extremo por la diabetes. Murió el primero de noviembre de 1928. Hoy en día, su tumba - es la única mujer - se encuentra en la Rotonda de Hombres Ilustres del Estado de México.

\section{CONCLUSIÓN}

Considero haber demostrado que el género biográfico ofrece un amplio abanico de posibilidades para recrear la historia de una vida y su contexto. Quizás, más que ningún otro género histórico, la biografía utiliza varias metodologías como la de la historia cultural, la de la vida cotidiana y otras más que enriquecen el apasionado quehacer del biógrafo. Los biógrafos se apasionan tanto en seguir la huella de sus personajes, que se convierte en una obsesión. Solo así es posible terminar con el fascinante reto que representa escribir una biografía, quehacer mental a la vez que emocional, porque el biógrafo se involucra con su personaje y acaso se enamora de él. De este sentimiento brota una disposición diferente del historiador cuando se convierte en biógrafo. De manera similar a la labor que realiza un pintor frente a su lienzo cuando intenta trazar un retrato, el biógrafo intenta con palabras retratar el alma de su personaje. Se adentra en su personalidad y en su temperamento y llega a conocer sus emociones, sus acciones, sus motivaciones, sus sentimientos, sus éxitos y sus fracasos, temas poco estudiados y acaso no tomados en cuenta por el común de los historiadores.

Mis décadas de experiencia como historiadora de la educación durante el Porfiriato (1876-1910) me dieron el conocimiento del contexto histórico; posteriormente intenté desarrollar, en mayor grado, la imaginación -que utiliza todo historiador para reconstruir el pasado- alimentada con una pequeña dosis de ficción, elementos que me ayudaron a retratar el significado de la vida de Laura Méndez de Cuenca, una trágica vida que transgredió las normas sociales y alcanzó a cambiar, en la medida de lo posible, el camino tradicional hogareño de las mujeres e impulsarlas hacia la modernidad, hacia la educación media y superior y el trabajo, aquello por lo cual serían libres y felices. Aquellos frutos sembrados de mujer moderna empezaron a germinar cuando, durante la década de los veinte del siglo pasado, varias mujeres desempeñaron puestos directivos en el ramo de la educación. Quizá la utopía de Laura, quien deseaba que el sexo femenino desempeñara las 
labores domésticas de esposa y madre, paralelamente al estudio y al trabajo -sin sacrificar ninguno- es aquello que estamos logrando las mujeres, no sin cierto abatimiento, desde hace varias décadas.

Su huella en la historia de la educación mexicana refleja, ante todo, la potencia de una sinfonía de palabras colmadas de sabias y modernas propuestas de cambio, algunas de ellas puestas en práctica en el aula por la misma autora, otras, aprendidas por las alumnas por medio de sus textos y, otras más, como la de los exámenes escritos, discutidas por las autoridades pedagógicas y tomadas en cuenta eventualmente por ellas y luego aterrizadas en leyes y decretos.

\section{FUENTES}

Acuña, Manuel. “A Laura", El Eco de Ambos Mundos, México, 9 de mayo de 1872.

Archivo Histórico Municipal de Tlalmanalco (AHMT), Sesiones de Cabildo 1852-1861, y Noticias sobre Estadística, 1853.

"Certificat de nationalité francaise", Archivo General de la Nación (AGN), Cartas de Seguridad, vol. 197, f. 356.

"Laura María Luisa Elena Méndez Lefort [Registro bautismal]", Archivo Parroquial de Ayapango (APA), Parroquia de Santiago, Ayapango, lib. 15, 1853-1858, reg., 6, p. 3.

Méndez de Cuenca, Laura. “A*****”, El Siglo Diez y Nueve, año XXIII, t. 56, No. 10672, México, 29 de marzo de 1874, 2, col. 5.

Méndez de Cuenca, Laura. "Tristeza”, Segundo Almanaque de Arte y Letras, México, febrero 1896, 51.

Méndez de Cuenca, Laura. "Informe del Kindergarten de Saint Louis Missouri", en Archivo Histórico de la Secretaría de Educación Pública (AHSEP), Personajes sobresalientes, Laura Méndez de Cuenca, leg. 1, 27 de enero, 1903, fs. 29.

Méndez de Cuenca, Laura. “El decantado feminismo”, El Imparcial, T. XXIII, No. 4065, México, 17 noviembre 1907, 10-11.

Méndez de Cuenca, Laura. "Informe sobre el sistema de educación popular en Alemania. Primera parte" (27 de enero, 1908), AGN, Secretaría de Estado y del Despacho de Instrucción Pública y Bellas Artes.

Méndez de Cuenca, Laura. "Informe sobre el sistema de educación popular en Alemania. Segunda parte" (13 de julio, 1908), AGN, Secretaría de Estado y del Despacho de Instrucción Pública y Bellas Artes. 
Méndez de Cuenca, Laura. "La mujer mexicana moderna en el nuevo hogar", El Pueblo, T. I, No. 673, México, 14 septiembre de 1916, 16.

Méndez de Cuenca, Laura. "Impresiones de viajes"; [“Un volumen de cuentos cortos"]; "Vacaciones. Novela de costumbres mexicanas"; "Los preciados. Novela de costumbres mexicanas"; "La dicha... hay que atraparla"; "Eureka, comedia en tres actos"; "La ley del embudo, Zarzuela en tres actos"; "Carmen, drama en tres actos"; "Novela de costumbres sin título"; ["Tres libros de lectura"]. En el Archivo Histórico de Ramón Beteta en el Colegio de México (AHRB), caja 49 , exp. 321.

P. P., en el suplemento Jueves de El Mundo. Ilustración Popular, México, 12 de junio, 1902.

\section{REFERENCIAS}

Bazant, Mílada. “La educación moderna, 1867-1911”. En Historia de la educación en la ciudad de México, coordinado por Pilar Gonzalbo Aizpuru y Anne Staples, 245-327. México: El Colegio de México, Centro de Estudios Históricos, Secretaría de Educación del Distrito Federal, 2012.

Bazant, Mílada (coord.). Laura Méndez de Cuenca: su herencia cultura. Tomo II. Poesía, cuentos y miscelánea. México: El Colegio Mexiquense A.C., Siglo XXI, 2011.

Bazant, Mílada (coord.). Laura Méndez de Cuenca: su herencia cultural. Tomo III. Educación, feminismo y crónicas de viaje. México: El Colegio Mexiquense A.C., Siglo XXI, 2011.

Bazant, Mílada. Laura Méndez de Cuenca: mujer indómita y moderna 1853-1928. Vida cotidiana y entorno. México: El Colegio Mexiquense, A.C., 2010.

Bazant, Mílada. Historia de la educación en el Porfiriato. México: El Colegio de México, 2006. Berman, Marshall. Todo lo sólido se desvanece en el aire. La experiencia de la modernidad. México: Siglo XXI, 2003.

Camarena, Mario y Laura Espejel. "Comunidad, hacienda y fábrica: formación y desintegración de Tlalmanalco". En Entre lagos y volcanes. Chalco Amecameca: pasado y presente, coordinado por Alejandro Tortolero, 481-520, México: Gobierno del Estado de México, 1982.

Dosse, François. El arte de la biografía: entre historia y ficción. México: Universidad Iberoamericana, 2007.

Echeverría, Bolívar. Las ilusiones de la modernidad. México: UNAM, El Equilibrista, 1997.

Escaja, Tina (comp.). Delmira Agustini y el Modernismo. Nuevas propuestas de género. Rosario: Beatriz Viterbo Editora, 2000.

Gonzalbo Aizpuru, Pilar. Introducción a la historia de la vida cotidiana. México: El Colegio de México, 2006.

Kelley, Donald. "El giro cultural en la investigación histórica". En La "nueva" historia cultural: la influencia postestructuralista y el auge de la interdisciplina, editado por J. Olabarri y F. J. Caspistegui, 35-48. España: Editorial Complutense, 1996. 
Kessler-Harris, Alice. “Why biography”. American Historical Review 114, 3 (2009): 625-630.

Lejeune, Philippe. Le pacte autobiographique. Paris: Seuil, 1975.

Le Goff, Jacques (dir.). La nouvelle histoire. Paris: Complexe, 1978.

Le Goff, Jacques. Histoire et memoire. Paris: Gallimard, 1988.

Marcus, Laura. "The Newness of the 'New Biography': Biographical Theory and Practice in the Early Twentieth Century". En Mapping Lives. The Uses of Biography, editado por Peter France y William St. Clair, 193-218. Nueva York: Universidad de Oxford, 2002.

Martínez Escobar, María de Lourdes Alvarado. La educación superior femenina en el México del siglo XIX. Demanda social y reto gubernamental. México: Facultad de Filosofía y Letras, UNAM, 2001.

Romero Chumacero, Leticia. “Un impulso de solidaridad: el feminismo de Laura Méndez de Cuenca". En Laura Méndez de Cuenca: su herencia cultural. Tomo III. Educación, feminismo y crónicas de viaje, coordinado por Mílada Bazant, 189-204. México: El Colegio Mexiquense A.C., Siglo XXI, 2011.

Seymour, Miranda. "Shaping the Truth". En Mapping Lives. The Uses of Biography, editado por Peter France y William St. Clair, 262-263. Nueva York: Universidad de Oxford, 2002.

Tortolero Villaseñor, Alejandro Constantino. De la coa a la máquina de vapor: actividad agrícola e innovación tecnológica en las haciendas mexicanas, 1880-1914. México: El Colegio Mexiquense A.C., Siglo XXI, 1995.

Woolf, Virginia. The Death of the Moth and other Essays. Nueva York: Harcourt, Brace And Company, 1942.

\begin{tabular}{|l|}
\hline $\begin{array}{l}\text { Bazant, Mílada. "Una musa de la modernidad: Laura Méndez de Cuenca } \\
\text { (1853-1928)". Revista Historia de la Educación Latinoamericana. Vol. } 15\end{array}$ \\
\hline No., 21, (2013): 19 - 50.
\end{tabular}

